\title{
Experience of the concentration of methotrexate evaluation in children with juvenile idiopathic arthritis
}

\author{
FV Rokhlina*, GA Novik, MF Dubko \\ From 18th Pediatric Rheumatology European Society (PReS) Congress \\ Bruges, Belgium. 14-18 September 2011
}

Juvenile idiopathic arthritis - one of the most common rheumatic disease in children (1:1000) [Timothy Beukelman et all, 2011]. The most effective basic drug is methotrexate, an initial dose of $15 \mathrm{mg} / \mathrm{m} 2 /$ week. Our study to determine the concentration of methotrexate in serum aims to develop a test system to clarify the reasons for lack of efficacy of methotrexate in some patients. The study currently includes 46 children (19 boys (41,3\%), 27 girls (58.7\%)) with different forms of JIA, according to the classification of ILAR. Systemic arthritis -9 children (20\%), arthritis oligoarticular - 9 $(20 \%)$, polyarticular arthritis - $15(34 \%)$, psoriatic arthritis - 1 (2\%), arthritis entesitis - 11 (24\%). Of the 46 children noone is in clinical remission off medication. 26 (56.5\%) children met the criteria of inactive disease.

Results of determining the concentration of methotrexate in children with JIA were distributed as follows $0-1 \mathrm{umol} / \mathrm{l}$ - 2,18\%; 1-1,5 umol/l - 34.78\%; 1,5-2 umol/1 - $17.39 \%$ 2-2,5 umol/l - 32.61\%; 2,5-3 umol/l - 8.69\% above 3 umol/l - 4,35\%. Among children with the results of the concentration of methotrexate up to $1.5 \mathrm{umol} / \mathrm{l}$ 88.24\% have signs of active disease (elevated ESR / CRP high / dysproteinemia / active joints). Low concentrations of methotrexate in $73.3 \%$ are associated with high levels of ESR and CRP. Among children with the results of methotrexate concentration above 1,5 umol/l signs of active disease manifestations are much rarer in $48,28 \%$ of cases.

Published: 14 September 2011

* Correspondence: faina.rokhlina@gmail.com

The State Medical Pediatric Academy of Saint-Petersburg, Russia
doi:10.1186/1546-0096-9-S1-P187

Cite this article as: Rokhlina et al: Experience of the concentration of methotrexate evaluation in children with juvenile idiopathic arthritis. Pediatric Rheumatology 2011 9(Suppl 1):P187.

Submit your next manuscript to BioMed Central and take full advantage of:

- Convenient online submission

- Thorough peer review

- No space constraints or color figure charges

- Immediate publication on acceptance

- Inclusion in PubMed, CAS, Scopus and Google Scholar

- Research which is freely available for redistribution

\section{Biomed Central}

